\title{
発電機速度の比例・微分・積分情報を基にした ファジー制御による電力系統安定化装置
}

\author{
正員檜山隆 (熊本大) \\ 准員 藤 木 俊 弘 (熊本大)
}

\section{Fuzzy Logic Power System Stabilizer using PID Information of Generator Speed}

Takashi Hiyama, Member, Toshihiro Fujiki, Associate (Kumamoto University)

\begin{abstract}
An advanced fuzzy logic control scheme has been proposed for micro-computer based power system stabilizer (PSS) to enhance the stability of power systems. In the proposed control scheme, additional integral information of generator speed is taken into account to enlarge the stability region together with propotional and differential information of generator speed. Namely, the advanced control rules are based on the PID information of generator speed. Various simulations have been performed subject to several types of large and small disturbances using a one-machine and an infinite-bus model system. In addition, comparison studies have been made between a conventional analog-type PSS and the fuzzy logic PSS. The results show that the stable region of the study system is highly enlarged up to the physically stabilizable boundary by the proposed fuzzy logic control scheme.
\end{abstract}

キーワード：電力系統安定化装置，ファジー制御，ディジタル制御，実時間制御

\section{1.はじめに}

大規模, 複雑化する電力系統におりて，その安定化 問題は重要な研究課題となってきている。安定化装置 に特に求められることは, 優れた応答特性とロバスト 性である。著者らは, 速度・加速度情報を用いたディ ジタル型ファジー制御装置を提案し, シミュレーショ ン・実験によって，その優れた制御性能について確認 してきた(1)〜(5)。ほかにも，この手法に基づいた種々 の報告がなされている(6)(7)。提案するファジ一制御規 則は非線形制御則であり，ロバスト性の高いものであ つたが，特定動作点で設計した制御パラメータを用い て，物理的に安定化可能なすべての動作点で，その制 御性能を保持するまでにはいたっていなかつた。その 原因は，位相差角が平衡点から大きくずれている場合 でも，速度・加速度が平衡点近傍にあれば，制御信号 が小さくなるため安定化に必要な制御量の確保が困難
となっていたことにある。そこで本論文では，位相差 角に相当する速度の積分情報を加味したファジー制御 規則を提案し，その有効性について検討を行ってい $ろ^{(8)(9)}$ 。この手法を用いることで，物理的に安定化が 可能である全領域に乱いて, 提案する安定化装置の制 御性能を大幅に改善することが可能であると考えられ る。

本論文では，提案する制御手法のアルゴリズムにつ いて述へ，その有効性を調べるために一機無限大母線 系統を用いたシミュレーションを行っている。その結 果, 従来の制御に比べ倀れた応答特性, ロバスト性を 有することを確認した。

\section{2. 制御手法}

今回提案する制御手法は, 励磁系に対する速度・加 速度情報を利用した従来型ファジー制御(1) (5) を拡張 したものであり，新たに速度の積分情報を加えてい 
る。すなわち，速度の比例・微分・積分情報を用いた 制御手法である。従来型ファジー制御は，安定領域内 での優れた応答特性と通常アナログ型 PSSに比べて かなり広い安定領域を有することがわかっている。し かし, 物理的に安定化可能な限界点までの安定化には いたっていない。このような場合でも，速度の積分情 報を用いることで安定化が可能となると考えられる。

$\langle 2 \cdot 1\rangle$ 信号処理 $\mathrm{A} / \mathrm{D}$ 变換により, 計算機内に 取り込まれる発電機状態量としては，角速度 $\omega$, 有効 出力 $P_{e}$ の 2 ケースを考慮している。図 1 (a)，(b) にこれら 2 ケースに対する剆定情報のフィルタリング 手法を示している。ここで, $H$ は慣性定数， $f_{0}$ は定 格周波数である。

これらのディジタルフィルタによって発電機角速度 偏差信号に相当する $Z_{s}(k)$ および, 角加速度信号, 位 相差角信号に相当する $Z_{a}(k), Z_{p}(k)$ が求められる。図 に拈いて， $H_{D R i}(i=1,2,3,4,5), H_{D I}$ はリセットフィ ル夕，積分器であり，それぞれ(1)，(2)式のように 周波数領域で表現されたものを双一次変換〔( 3 )式〕を 用いて離散化したものである〔(4)，（5)式〕電力系 統における外乱には種々のものがあり，外乱印可前後 の系統状態は必ずしも同一とはいえない。従って，図 1に示すように，リセットフィルタによる定状分の力 ットが必要となってくる。最終の定状状態では, 加速 度, 速度偏差, 位相差角に相当する信号 $Z_{a}, Z_{s}$ 扝よ び $Z_{p}$ 注すべて零となる。

$$
\begin{aligned}
& H_{R i}(s)=\frac{s T_{R i}}{1+s T_{R i}} \\
& H_{I}(s)=1 / s \\
& s=\frac{2}{\Delta T} \frac{1-z^{-1}}{1+z^{-1}} \\
& H_{D R i}\left(z^{-1}\right)=\frac{B_{i}\left(1-z^{-1}\right)}{\left(1+B_{i}\right)+\left(1-B_{i}\right) z^{-1}} \\
& H_{D I}\left(z^{-1}\right)=\frac{\Delta T}{2} \frac{1+z^{-1}}{1-z^{-1}}
\end{aligned}
$$

ここで， $\Delta T$ はサンプリング間隔， $T_{R i}$ はりセットフ ィルタの時定数であり, 以下の計算ではそれぞれ

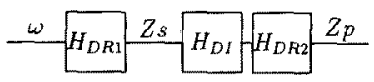

(a) 速度信号に対するフィルタリング

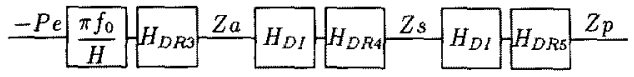

(b) 有効出力信㝍に対するフイルタリング

図 1 フィルタリング

Fig. 1. Filtering.
$0.02 ， 3.0 \mathrm{~s}$ と設定している。また $B_{i}=2 T_{R i} / \Delta T$ であ る。それぞれの観測信号に対して， $Z_{s}(k), Z_{a}(k)$, $Z_{p}(k)$ は次のように求められる。

（i）速度信号を用いた場合

$$
\begin{aligned}
& Z_{s}(k)=H_{D R 1} \omega(k) \\
& Z_{a}(k)=\frac{Z_{s}(k)-Z_{s}(k-1)}{\Delta T} \\
& Z_{p}(k)=H_{D I} H_{D R 2} Z_{s}(k)
\end{aligned}
$$

（ii）有効出力信号を用いた場合

$$
\begin{aligned}
& Z_{a}(k)=-H_{D R 3} P_{e}(k) \\
& Z_{s}(k)=H_{D I} H_{D R 4} Z_{a}(k) \\
& Z_{p}(k)=H_{D I} H_{D R 5} Z_{s}(k)
\end{aligned}
$$

〈2・2〉 従来型ファジー制御 ${ }^{(1) \sim(5)}$ 従来型ファジ 一制御は, 位相平面上(図 2$)$ の動作点 $p(k)=\left\{\left(Z_{s}(k)\right.\right.$, $\left.A_{s} Z_{a}(k)\right\}$ に応じて,ファジー論理的に制御信号を決 定するものである。ただし， $A_{s}$ は加速度情報 $Z_{a}(k)$ に対するスケーリングファクタである。発電機の動作 点 $p(k)$ が領域 $A$ にある場合は発電機に対して減速制 御が要求され，領域 $B$ にある場合には逆に発電機に 対して加速制御が要求される。減速制御，加速制御の 切換光は第 2 ・第 4 象限にある切換線によって行われ る。 $A$ と $B$ のつの領域は単調な台形型メンバシッ

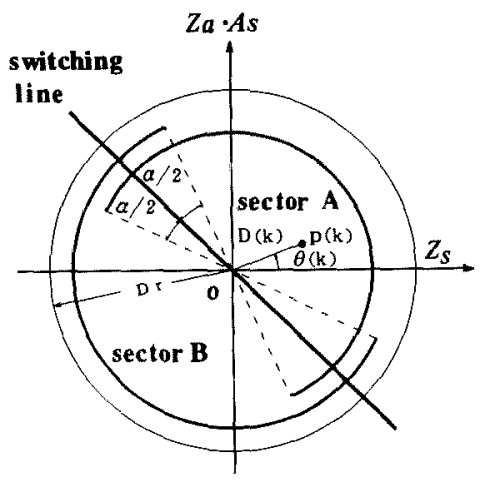

図 2 位相平面図 $A$

Fig. 2. Phase plane $A$.

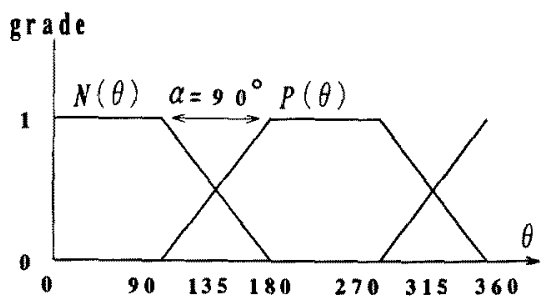

図 3 メンバシップ関数

Fig. 3. Membership functions. 
プ関数を用いて図 3 のように表現できる。ここで, $N\{\theta(k)\}$ が減速領域 $A$, また $P\{\theta(k)\}$ が加速領域 $B$ のメンバシップ関数である。以上より, 系統安定化信 号 $U(k)$ は重み付き平均により次式で与えられる。

$$
U(k)=\frac{N\{\theta(k)\} U_{\max }-P\{\theta(k)\} U_{\max }}{N\{\theta(k)\}+P\{\theta(k)\}} G(k)
$$

$U_{\max }$ は安定化信号の制約であり，また $G(k)$ は原点 から $p(k)$ までの距離に関するゲインで, パラメータ $D_{r}$ を用いて次式により表される。

$$
D(k) \leqq D_{r} \quad \text { のとき } G(k)=D(k) / D_{r}
$$

$$
D(k)>D_{r} \text { のとき } G(k)=1.0
$$

ただし， $D(k)$ は原点から動作点までの距離 $|p(k)|$ を 表している。

$\langle 2 \cdot 3\rangle$ 三次元情報を用いたファジー制卸(8)(9)

提案する制御は図 4 の位相空間によって表せるよう

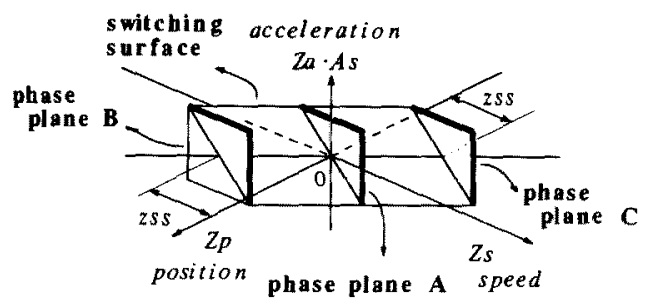

図 4 位相空間

Fig. 4. Phase space.

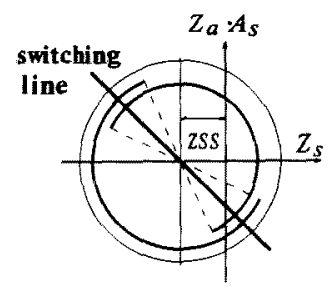

図 5 位相平面 $B$

Fig. 5. Phase plane $B$.

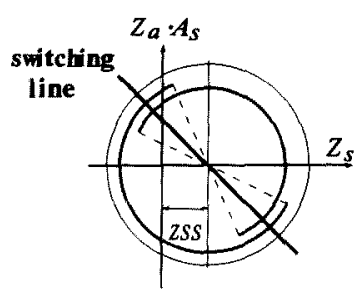

図 6 位相平面 $C$

Fig. 6. Phase plane $C$.
な三次元型ファジー制御である。同図では三次元空間 における切換線を切換面として示している。図に示さ れるように，速度の積分情報 $Z_{p}$ が大きくなるにつれ て，切換線を速度偏差 $Z_{s}$ 軸に沿って負の方向に， $Z_{p}$ が小さくなるにつれて正の方向に移動させている。従 来型制御では, 速度の積分情報 $Z_{p}$ の状態にかかわら ず，位相平面 $A$ (図 2 参照)によって制御信号が決 定され，加減速領域の調整ができなかった。それに対 して，提案する制御においては $Z_{p}$ に応じたシフト量 ZSS 用いて切換線をシフトすることで, 加減速領 域を変化させることができる。この加隇速領域の変更 により，従来は十分な制御量が得られずに不安定にな っていたケースの安定化が可能となる。図 5 , 図 6 は 位相空間における位相平面 $B, C$ を表している。 $Z_{p}$ が正のときの位相平面 $B$ では隇速領域 (sector $A$ ) が， $Z_{p}$ が負のときの位相平面 Cでは加速領域（sector B）がそれぞれ広がっていることがわかる。また， アルゴリズム的にみても，従来のファジー制御装置へ の入力が次のように変わるだけで簡潔である。

$$
\left(Z_{s}, Z_{a}\right) \rightarrow\left(Z_{s}+Z S S, Z_{a}\right)
$$

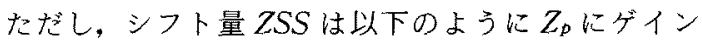
$S_{g}$ を乗じたものである。ただし， $Z_{p \min }$ は安定領域内 の制御の行き過ぎを防ぐために設けた不感带である。

$$
\left|Z_{p}\right| \geqq Z_{p \min } \quad \text { のとき } Z S S=S_{g} \cdot Z_{p}
$$

$$
\left|Z_{p}\right|<Z_{p \min } \text { のとき } Z S S=0.0
$$

\section{3. 例題 系 統}

提案する制御手法の有効性を確認するために，図 7 に示す一機無限大母線系統を用いて計算機シミュレー ションを行っている(10)。

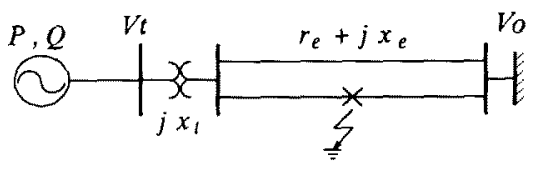

図 7 一機無限大母線系統

Fig. 7. One-machine infinite-bus system.

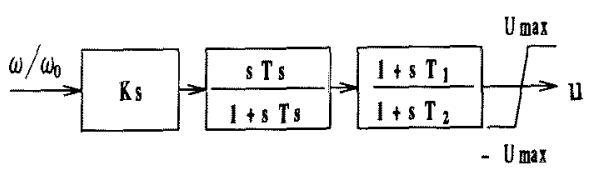

図 8 通常アナログ型安定化装置

Fig. 8. Conventional analog-type PSS. 
また，比較検討のために使用した通常アナログ型 PSS の椿成図を図 8 に示す。

\section{4. パラメータ設定}

今回のシミュレーションに用いた制御装置のパラメ 一夕は，順序付最適化手法により個々のパラメー夕を 順番に最適化することで, 次の離散型評価関数 Index を最小にするものを選んだ。

$$
\text { Index }=\sum_{k}\left[\left\{\Delta \omega(k)^{2}+U(k)^{2}\right\}\{k \Delta T\}^{2}\right]
$$

なお，パラメータ設定を行う際の観測信号には速度信 号を用いたが，ここで設定されたパラメー夕值は有効 出力信号を観測信号とした場合でもそのままの值で使 用することができる。

（1）従来型ファジー制御のパラメータ設定

三相地絡事故自然消隇外乱 $(0.1$ 秒継続，発電機有 効出力 $P=1.0 \mathrm{pu}$, 発電機無効出力 $Q=0.3 \mathrm{pu} ） の$ も とで, 調整可能なパラメータ $A_{s}, D_{r}$ および $\alpha$ の設定 を行った。設定にあたっては，これら三つのパラメー 夕のうち順次一つのパラメータを選択し, シミュレー ションにより評洒関数を最小とするパラメータ值を求 めている。以後の繰返しにおいて，パラメー夕值の変 更がなくなったところで，これらのパラメータの繰返 し修正を終つしている。

$$
\begin{array}{ll}
\text { 〔ステップ 1) } & D_{r}=1, \alpha=90 \text { に固定 } \\
& A_{s} \text { の最適化 } \rightarrow 0.2 \\
\text { [ステップ2] } & A_{s}=0.2, \alpha=90 \text { k固定 } \\
& D_{r} \text { の最適化 } \rightarrow 1.1 \\
\text { [ステップ } 3 \text { ] } & A_{s}=0.2, D_{r}=1.1 \text { に固定 } \\
& \alpha \text { の最適化 } \rightarrow 35 \\
\text { [ステップ4] } & D_{r}=1.1, \alpha=35 \text { k固定 } \\
& A_{s} \text { の最適化 } \rightarrow 0.2
\end{array}
$$

[ステップ4]での各パラメータ値が[ステップ 3]で の各值と一致するため，以後の繰返しではパラメータ 値の変更恬なくなる。従って，(ステップ 4)で求まっ たパラメータが最適パラメータとなる。各パラメータ の初期值，繰返し覑序を変更して最適化を行った場合 も同様の結果が得られた。従って，これらのパラメー 夕値は評価閣数の大域的極小偲を与えるものであると いえる。

（2）提案型ファジー制御のパラメー夕設定

ゲイン $S_{\theta}$ は事故後回線遮断外乱(三相地絡事故 0.1 秒継続， $P=1.08 \mathrm{pu}, Q=0.3 \mathrm{pu} ） に$ 対して最適化を 行った。この外乱に対して発䉓機の安定化が可能とな る促来型ファジー制御のパラメータを(1) 項と同様の
手法で探索したが，存在しなかった。すなわち，従来 型ファジー制御ではこの外乱に対する安定化は不可能 であった。この外乱に対する安定化のため, 提杵型フ アジー制御のパラメータの設定を以下の手順で行っ た。ただし， $A_{s}, D_{r}, \alpha$ の設定值としては（1)項で求 めたパラメー夕值を用いている。更に, 安定領域内で の制御の行き過ぎによる応答特性の劣化を防ぐため に, (1) 項と同じ外乱のもとで不感帯 $Z_{p \min }$ を最適化 している。

〔ステップ1〕

$A_{s}=0.2, D_{\tau}=1.1, \alpha=35, Z_{p \min }$ $=0$ 结固定

$S_{g}$ の最適化 $\rightarrow 4.2$

〔ステップ 2) $\quad A_{s}=0.2, D_{r}=1.1, \alpha=35, S_{\theta}$ $=4.2$ に固定

$Z_{p \min }$ の最適化 $\rightarrow 0.35$

（3）アナログ型PSSのパラメータ設定

(1) 項と同じ外乱に対して評価関数值を最小とする パラメータの設定を行った。ただし，位相進み補償器 に含まれる時定数 $T_{2}$ は 0.02 秒に固定している。

$$
\begin{aligned}
& \text { 〔ステップ1〕 } T_{1}=0.5 \text { に固定 } \\
& K_{s} \text { の最適化 } \rightarrow 50 \\
& \text { 〔ステップ 2〕 } K_{s}=50 \text { に固定 } \\
& T_{1} \text { の最適化 } \rightarrow 0.33 \\
& \text { 〔ステップ } 3 \text { 〕 } T_{1}=0.33 \text { に固定 } \\
& K_{s} \text { の最適化 } \rightarrow 62 \\
& \text { 〔ステップ } 4 \text { 〕 } K_{s}=62 \text { に固定 } \\
& T_{1} \text { の最適化 } \rightarrow 0.33
\end{aligned}
$$

\section{5. シミュレーションによる制御性能の検証}

前章で求めた制缻パラメータを用いて，各制御装置 の制御性能を検証した。なお，シミュレーション1 〜 は観測信号として速度を用いている。有效出力を 観測信興とした場合も同等の制御が可能であり，シミ ュレーション 5 でそのことを示す。

表 1 安定限界極限電力（事故後回線遮断の場合）

Table 1. Critical power output (isolation of faulted line).

\begin{tabular}{c|c|c|c|c}
\hline \multirow{2}{*}{$\begin{array}{c}\text { 事故時關 } \\
(\mathrm{s})\end{array}$} & \multicolumn{4}{|c|}{ 安定限界極限電力 $(\mathrm{pu})$} \\
\cline { 2 - 5 } & 通常型 & $\begin{array}{c}\text { 従来型 } \\
\text { ファジー }\end{array}$ & $\begin{array}{c}\text { 提案型 } \\
\text { ファジー }\end{array}$ & $\begin{array}{c}\text { 運用可能 } \\
\text { 最大出力 }\end{array}$ \\
\hline 0.00 & 1.11 & 1.16 & 1.17 & 1.20 \\
0.02 & 1.10 & 1.14 & 1.17 & 1.20 \\
0.04 & 1.07 & 1.12 & 1.17 & 1.20 \\
0.06 & 1.05 & 1.08 & 1.15 & 1.16 \\
0.08 & 1.01 & 1.06 & 1.12 & 1.12 \\
0.10 & 0.98 & 1.03 & 1.08 & 1.08 \\
0.12 & 0.94 & 0.99 & 1.04 & 1.04 \\
\hline
\end{tabular}




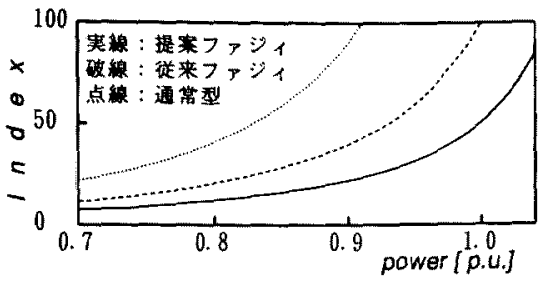

事故後回線遮断，事故 $0.1 \mathrm{~s}$

図 9 Indexの変化 (出力を上げた場合)

Fig. 9. Performance index vs. power output (isolation of faulted line after $0.1 \mathrm{~s}$ ).

（1）シュミレーション 1 事故後回線遮断（三 相地絡事故 $0 \sim 0.12$ 秒継続）において発電機出力を增 加していったときの安定限界極限出力の比較を行っ た。表 1 は事故時間を変えたときに各制御で安定化可 能な安定限界極限電力を示している。ここで運用可能 最大出力というのは，100\%の制動をかけた場合に角 速度偏差が零点を交差し(第 1 波における安定)，加 つ定常動作点の存在する最大有効電力のことである。 同表を見ると，提案型の制御により運用可能最大出力 近くまで制御可能であることがわかる。

出力の増加に伴うIndex の変化を図 9 に示す（事 故継続時間 $0.1 \mathrm{~s}$ \%。同図汃らも，提案型制御 23 応答特 性，ロバスト性に優れていることがわかる。また，図 10 , 図 11 に運用可能最大出力点（事故 0.1 秒継続, $P=1.08 \mathrm{pu}, Q=0.3 \mathrm{pu}$ ）における応答波形，制御信 号を示している。提案型制御は速度の積分情報を考慮 して十分な制御量を確保しており，その結果，従来型 ファジー制御，通常アナログ型制御では制御不可能な 動作点での安定化がなされている。

図 12, 図 13 はアナログ型 PSS の安定限界極限電 力点 (事故 0.1 秒継続, $P=0.98 \mathrm{pu}, Q=0.3 \mathrm{pu}$ ) で のシミュレーション結果である。このケースでは提案 型ファジー制御を用いた場合，動摇の整定時間が他の 制御方式よりも短くなっており，その優れた制御性能 が確認される。

図 14(a)，(b)仙，従来型ファジー制御の安定限 界極限電力近傍点 (事故 $0.1 \mathrm{~s}$ 継続, $Q=0.3 \mathrm{pu}, P=$ 1.03 または $1.04 \mathrm{pu})$ でのシミュレーション結果を位 相平面上にプロットしたものである。(a)図では従来 型ファジー制御が，切換線上に治って動作点を運んで 枋り，制御の行き過ぎもなく良好な制御であるように 見えるが，整定時間に関しては提案型制御のほうが早 い。このケースより出力を $0.01 \mathrm{pu}$ 增加させると, (b)図の上うに従来型ファジー制御では安定化信号の 不足により不安定になってしまうが，提案型制御では
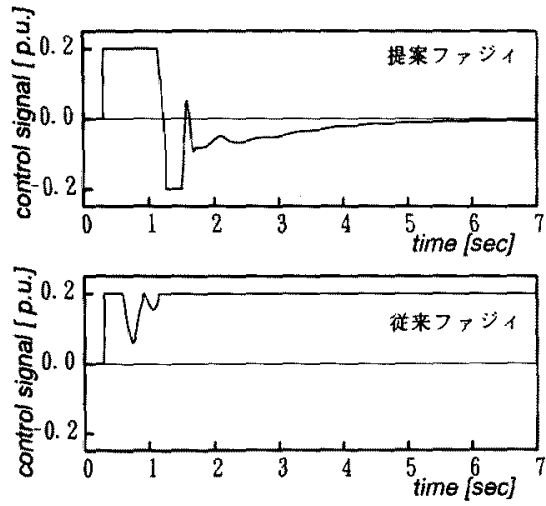

事故後回線遮䶊，事故 $0.1 \mathrm{~s}$, 出力 $1.08 \mathrm{pu}$ 図 10 制御信号

Fig. 10. Stabilizing signal (isolation of faulted line after $0.1 \mathrm{~s}$, power output $=$ $1.08 \mathrm{pu})$.
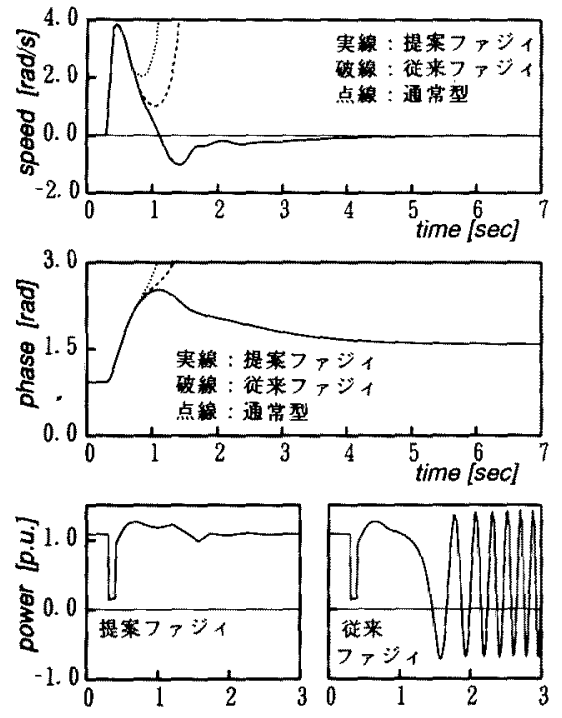

事故聁回線遮析, 事故 $0.1 \mathrm{~s}$, 出力 $1.08 \mathrm{pu}$ 上加ら速度偏差, 位相差角, 有効出力

图 11 応答波形

Fig. 11. Time responses (isolation of faulted line after $0.1 \mathrm{~s}$, power output $=$ $1.08 \mathrm{pu})$.

安定化が可能である。なおこれらの図に示されるよ うに，いずれの場合も通常アナログ型制御での安定化 は不可能である。

（2）シミュレーション2 事故回線を遮断した 場合において出力を $1 \mathrm{pu}$ に固定し, 事故時間を延長 していった場合の安定化可能な限界故障除去時間と各 制御でのIndex を調べた。安定化可能な限界故障除 

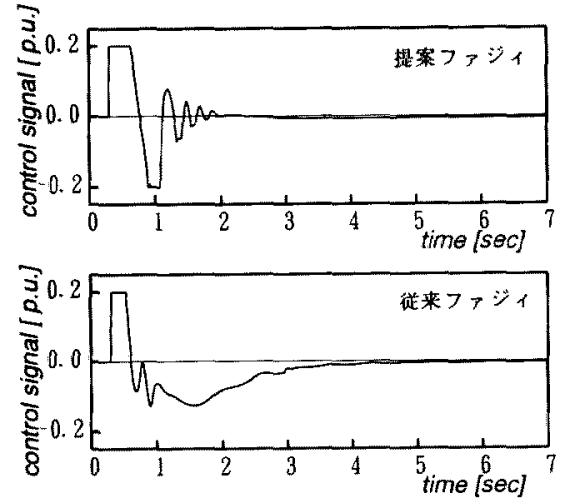

事故後回線遮断，事故 $0.1 \mathrm{~s}$, 出力 $0.98 \mathrm{pu}$

図 12 制御信号

Fig. 12. Stabilizing signal (isolation of faulted line after $0.1 \mathrm{~s}$, power output $=$ $0.98 \mathrm{pu})$.
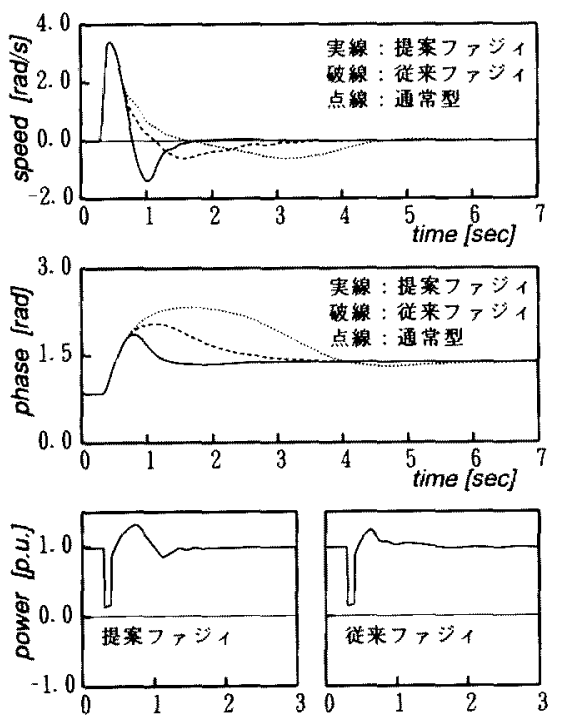

事故後回線遮断, 事故 $0.1 \mathrm{~s}$, 出力 $0.98 \mathrm{pu}$ 上から速度偏差, 位相荎, 有効出力

园 13 応答波形

Fig. 13. Time responses (isolation of faulted line after $0.1 \mathrm{~s}$, power output = $0.98 \mathrm{pu})$.

去時間は，通常アナログ型制御では $0.09 \mathrm{~s}$, 従来型つ アジー制卸では $0.11 \mathrm{~s}$ ，提案型制御では $0.14 \mathrm{~s}$ とな つた。また，Indexの変化を図 15 に示す。この場合 も, 提案型ファジー制御の優れた応答特性とロバスト 性が確認できる

（3）シミュレーション3事故自然消滅（三相 地絡事故 $0.02 \sim 0.12 \mathrm{~s}$ ）において出力它增加していっ

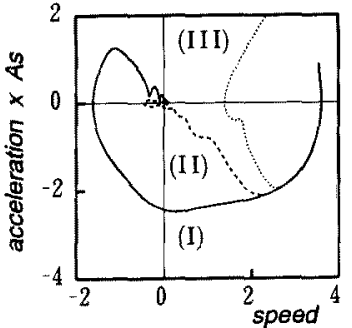

(a) 事故後回線遮断

事故 $0.1 \mathrm{~s}$ 、出力 $1.03 \mathrm{pu}$

(I)：提案型ファジ一制郝,

(III)：通常アナログ型制御

図 14 位相平面上の動作点軌跡

Fig. 14. Phase plane trajectories.

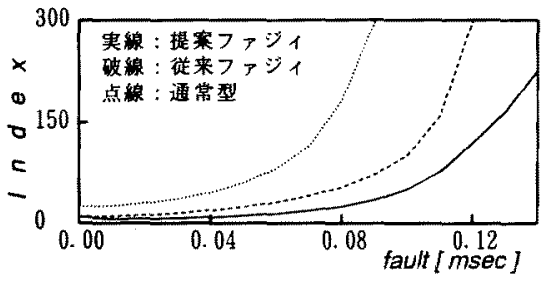

事故後回線遮断，出力 1 pu

図 15 Index の変化（事故時間延長）

Fig. 15. Performance index vs. duration time of fault (isolation of faulted line, power output $=1.0 \mathrm{pu}$ ).

表 2 安定限界極限電力（自然消滅外乱の場合）

Table 2. Critical power output vs. fault duration time.

\begin{tabular}{|c|c|c|c|}
\hline \multirow{2}{*}{$\begin{array}{c}\text { 事故時間 } \\
\text { (s) }\end{array}$} & \multicolumn{3}{|c|}{ 安定限界極艮電力（pu） } \\
\hline & 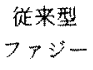 & $\begin{array}{l}\text { 提案型 } \\
7 ァ シ ー\end{array}$ & $\begin{array}{l}\text { 傕用可能 } \\
\text { 最大出力 }\end{array}$ \\
\hline 0.02 & 2.01 & 2.01 & 2.01 \\
\hline 0.04 & 2.01 & 2.01 & 2.01 \\
\hline 0.06 & 1.94 & 1.94 & 1.94 \\
\hline 0.08 & 1.75 & 1.75 & 1.75 \\
\hline 0.10 & 1.60 & 1.60 & 1.60 \\
\hline 0.12 & 1.47 & 1.47 & 1.47 \\
\hline
\end{tabular}

たときの安定限界極限出力の比較を行った。結果をま とめたものが表 2 である。従来型，提案型ともに運用 可能最大出力までの制御が可能であった。

図 16，図 17 は事故時間 $0.02 ， 0.1 \mathrm{~s}$ の各ヶースで, 出力を増加させた場合の Index の变化を示している。 事故時間が 0.02 sのときは不感带の効果により, 両 ファジー制御が同等の制御を行っていることがわか

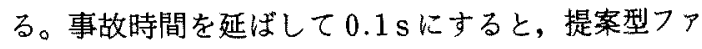
ジー制卸のIndex 值がやや大さくなるが，活ほ同等 


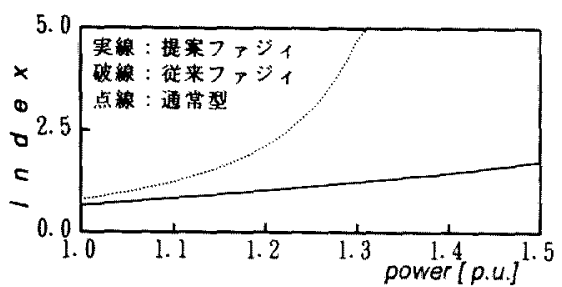

自然消隇, 事故時間 $0.02 \mathrm{~s}$

図 16 Index の変化 (出力を上げた場合)

Fig. 16. Performance index vs. power output (fault duration time $=0.02 \mathrm{~s}$ ).

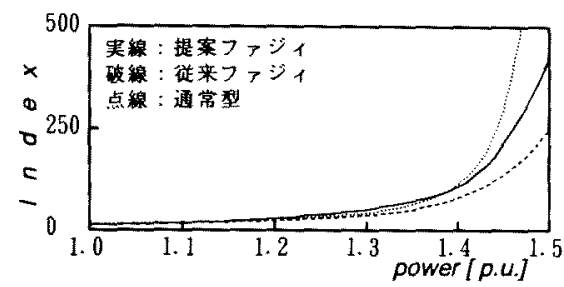

自然消減，事故時闃 $0.10 \mathrm{~s}$

図 17 Indexの変化 (出力を上げた場合)

Fig. 17. Performance index vs. power output (fault duration time $=0.1 \mathrm{~s}$ ).

\section{の制御が行われている。}

図 18, 図 19 に事故時間 $0.1 \mathrm{~s}$, 出力 $1.58 \mathrm{pu}$ にお ける応答波形と制御信号を示している。応答波形より 両ファジー制御の整定時間に差がないことがわかる。 提案する制御が大をく動作点莸動かす性質上, Index 值も若干大きくなっているが，整定時間に差がなく， むしろ大きく動作点を動かすことで，事故回線遮断外 乱における顕著なロバスト性が実現されていると考え られる。なお，表 2 において通常アナログ型制御での 安定限界をのせていないが，これは発電機出力を上げ た場合に持続振動が発生し，安定限界が確定できなか つたことによる。

(4) シミュレーション4 一般にバンバン型制 御では，小信号外乱に十分適応できないことが指摘さ れている。今回提案しているファジ一制御規則も，バ ンバン制御をべースとした制御規則であるので，小信 号外乱に対する制御性能を検討する必要がある。ここ で，1秒間継続するパルス状外乱，ステップ状外乱 （ともに外乱サイズ $0.1 \mathrm{pu}$ )を機械的入力に与えシミ ュレーションを行つた。いずれの場合も提案型ファジ 一制御, 従来型ファジー制御により同等の制御効果が 得られており，通常アナログ型制御に比べて優れた応 答特性を有している。
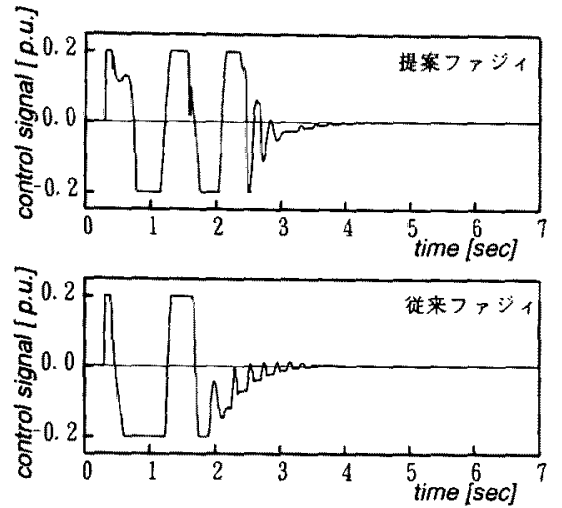

事故自然消滅，事故 $0.1 \mathrm{~s}$, 出力 $1.58 \mathrm{pu}$ 図 18 制御信号

Fig. 18. Stabilizing signal (fault duration time $=0.1 \mathrm{~s}$, power output $=1.58 \mathrm{pu}$ ).
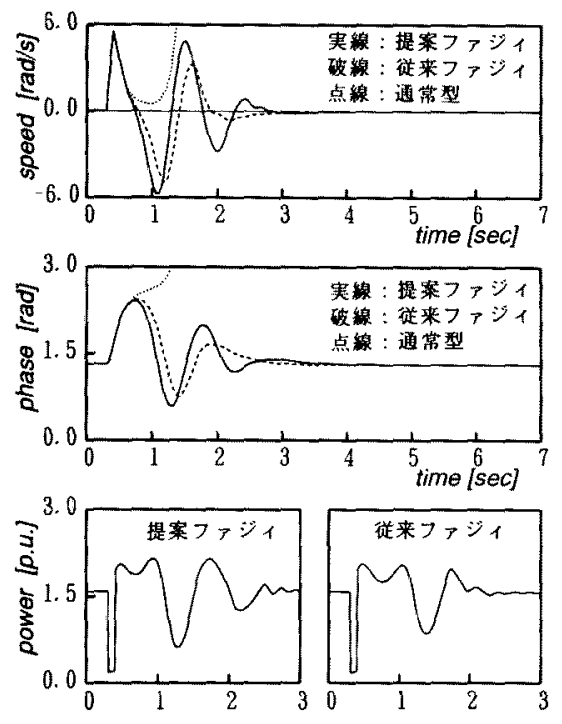

事故自然消隇、事故 $0.1 \mathrm{~s}$, 出力 $1.58 \mathrm{pu}$ 上加方速度编差, 位相差角, 有妨出力

図 19 応答波形

Fig. 19. Time responses (fault duration time $=0.1 \mathrm{~s}$, power output $=1.58 \mathrm{pu}$ ).

（5）シミュレーション5 ここでは，観測信号 に有効出力信号を用いた場合のシミュレーション結果 を示している。信号処理に用いるディジタルフィルタ を図1(b)のようにすることで，制御装置のパラメー 夕設定潅測信号に速度信号を用いた場合と同じ值と することができる。図20は外乱として三相地絡事故 （事故後回線遮断）を与えたときの応答波形である。 ただし, 事故時間 $0.1 \mathrm{~s}$, 有効出力は運用可能最大出 
表 3 小信号動作に扔けるIndex

Table 3. Performance index subject to small disturbance.

\begin{tabular}{c|c|c}
\hline \multirow{2}{*}{ 制御方式 } & \multicolumn{2}{|c}{ Index } \\
\cline { 2 - 3 } & $\begin{array}{c}\text { パルス状外乱 } \\
\text { (1 秒閪継続) }\end{array}$ & ステップ状外乱 \\
\hline 提案型ファジー制御 & 3.291 & 0.1991 \\
\hline 徉来型ファジー制御 & 3.291 & 0.1991 \\
\hline 通常アナログ型制御 & 4.482 & 0.5681 \\
\hline
\end{tabular}

$P=1.0 \mathrm{pu}, Q=0.3 \mathrm{pu}$, 外乱サイス $0.1 \mathrm{pu}$
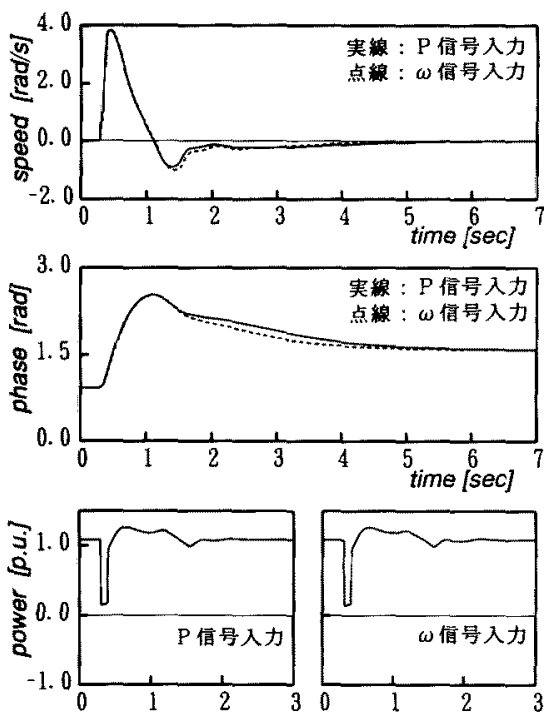

事故捘回線遮断, 事故 $0.1 \mathrm{~s}$, 出力 $1.08 \mathrm{pu}$ 上加占速度编差，位相差角，有奻出力

図 20 応答波形

Fig. 20. Time responses (isolation of faulted line after $0.1 \mathrm{~s}$, power output $=$ $1.08 \mathrm{pu})$.

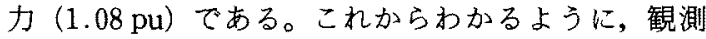
信号として有効出力を用いた場合でも，速度を観測し た場合と同等の制御が可能である。観測信号として有 効出力を用いることにより，加速度信号 $Z_{a}$ を得ると きの微分処理がなくなり，湘定雑音対策として有効で あると考えられる(3)。

\section{6. まとめ}

発電機速度の比例・微分・積分情報を用いて制御信 号を決定する新しいファジー制御規則を提案した。こ の制御菨置は, 従来型ファジー制御の位相平面を速度 の積分情報に応じてシフトすることで，加減速領域を 変更できるような構成となっている。制御器のパラメ
一タの決定は，まず通常動作点で応答特性に優れた制 御性能を有する従来型ファジー制御のパラメータを最 適化し，次に従来型の制御では安定化が不可能となる 動作点で，新しく導入した切換線をシフトするための パラメータを最適化している。この結果, 得られる制 御藷置は従来のファジー制御に比べてほほ同等な応答 特性と，より大きなロバスト性をもっている。

提案する手法の制御性能を検討するために, 一機無 限大母線系統を例題系統とした計算機シミュレーショ ンを行い，その有効性を確認した。特に，事故回線遮 断を外乱として与えた堭合, 提案型制御は運用可能最 大出力近傍の動作点まで安定化が可能であり，その有 効性が顕著であった。また，制御の行き過ぎによる応 答特性の出化を防ぐために不感带を設けたが，それに よって安定領域内の動作点でも従来型ファジー制御と ほほ同等の制御を行うことができた。

今後は，提案する制御方式を多機系統へ適用したシ ミュレーション，小型発電機を用いた実験的考察を行 いそその制御性能の検証を行う予定である。

(平成 4 年 12 月 16 日受付, 同 5 年 6 月 22 日再受付)

\section{文献}

(1) T. Hiyama \& T. Nakano: "Application of fuzzy control for stabilization of electric power system", Proc. Interna. tional Workshop on Fuzzy System Applications, lizaka, Japan, p. 71 (1988)

(2) T. Hiyama \& T. Sameshima: "Fuzzy logic control scheme for on-line stabilization of multi-machine power system", Fuzzy Sets \& System, 39, No. 2, 181 (1991)

(3) T. Hiyama, et al.: "Fuzzy logic stabilizer with digital compensation for stability enhancement of multi-machine power system", Proc. 3rd Symposium on Expert System Application of Power System, p. 455 (1991)

（4）㭘山 隆・壾宮政彦：「ファジイ制衙則を用いたデイジタル

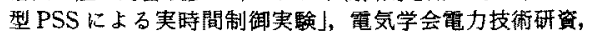
PE-92-85 (平 4)

(5) T. Hiyama: "Real time control of micro-machine system using micro-computer based fuzzy logic power system stabilizer", 1993 IEEE PES Winter Meeting, No. WM128$9 \mathrm{EC}$,

（6） M. A. Iskander - 石関光男，他：「測定雑音を考慮しファジ 亿制御を用いた電力系統の安定化制御」，平 4 電気学会電 力・エネルギー部門大会，I，p. 43

（7） M. A. Iskander - 佐藤仁志，他：「角速度と電力を測定しフ アジイ制御を用いた采統安定化装置】，電気学会電力技術所 瓷, $\mathrm{PE}-92-83$ (平 4 )

（8）檜山 隆・藤木俊弘：「ファジイ制御别の切りかえによる過 渡安定度の改善」, 平 4 電気学会電力・エネルギ一部門大会, II, p. 19

（9）㭘山 隆・藤木佼弘：「位相差角情報を加味したファジィ制 御による過渡安定度の改䇴」, 電気学会電力技術研资，PE92-81 (平 4)

(10) Yao-nan Yu: Electric Power System Dynamics (1983) Academic Press, Inc., Canada 


\section{檜山隆 (正員)}

昭和 22 年 3 月 14 日生。 46 年 3 月京 都大学大学院工学研究科修士課程電気専 攻修了。同年 4 月熊本大学工学部電気工 学科助手, 54 年 1 月同講師, 57 年 1 月 同助教授, 平成元年 6 月同電気情報工学科教授, 現在に至 る。工学博士。 60 年 5 月 61 年 9 月文部省在外研究員 (長期)として, アメリカ・ニューヨーク州クラークソン大 学へ出張。この間, 配電系統における高調波分布の実測お よび解析に関するプロジェクトに参加。主として, 電力系
統の安定化制御に関する研究に従事。日本計測自動制御学 会, 日本太陽エネルギー学会, IEEE 会員。

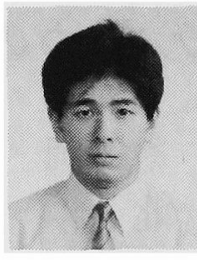

昭和 42 年 8 月 13 日生。平成 5 年 3 月 熊本大学大学院工学研究科電気情報工学 専攻修了。同年 4 月九州松下電器(株) 入 社, 現在に至る。 